\title{
Academic dishonesty, Type A behavior, and classroom orientation
}

\author{
JENNIFER WEISS, KIM GILBERT, and PETER GIORDANO \\ Belmont University, Nashville, Tennessee \\ and \\ STEPHEN F. DAVIS \\ Emporia State University, Emporia, Kansas
}

\begin{abstract}
One hundred eighty-three college students served as subjects in an investigation of relations among academic dishonesty, Type $A$ behavior, and classroom orientation. A positive association was found among learning orientation, Type $\mathbf{A}$ behavior, and lower levels of academic dishonesty. Grade orientation, Type B behavior, and higher levels of academic dishonesty were also positively associated. The implications of these findings are discussed.
\end{abstract}

Academic dishonesty has become a major problem in higher education. Research conducted over the past 50 years has shown an increase in the rate of cheating; Drake (1941) reported a $23 \%$ rate of cheating, whereas Hetherington and Feldman (1964) reported a rate of $82 \%$. Davis, Grover, Becker, and McGregor (1992) found that self-reported cheating rates in larger, state and private institutions ranged from $40 \%$ to $60 \%$.

Davis, Grover, Becker, and McGregor (1992) also found that the self-reported cheating rates at small, private, liberal arts colleges were significantly lower than those at larger, state and private institutions. On the basis of these results, we would expect students at Belmont University, a small, private, liberal arts institution, to report relatively low rates of cheating.

Competition for grades may contribute to academic dishonesty. Drake (1941) included stress and the pressure for good grades among the factors in academic dishonesty. Singhal (1982) reported that $68 \%$ of the students surveyed believed that competition for grades was the major reason for cheating. Keller (1976) reported that $69 \%$ of his student subjects held this belief.

Competitive striving for achievement is one of the primary characteristics of the Type A behavior pattern (Friedman \& Rosenman, 1977). Since Type A behavior includes a competitive component, and competition for grades is arguably a factor that contributes to cheating, it is hypothesized that cheating and Type A behavior will be positively related. Conversely, Type B behavior, defined as the absence of Type A characteristics, should be related to lower levels of cheating.

Classroom orientation is another factor that may be related to academic dishonesty and Type A behavior. Eison

Correspondence should be addressed to Peter Giordano, Department of Behavioral Sciences, Belmont University, 1900 Belmont Blvd., Nashville, TN 37212-3757; or to S. F. Davis, Department of Psychology, Emporia State University, 1200 Commercial, Emporia, KS 66801-5087.
(1981) has suggested that a student's academic behavior is influenced by two orientations to the classroom situation, learning orientation and grade orientation. Learning orientation describes the attitude held by students who perceive college as an opportunity for learning and personal growth. Grade orientation refers to the attitude held by students who are preoccupied with making a good course grade. Students who are grade oriented tend to be more competitive than learning-oriented students. This relation suggests that grade orientation will be positively related to Type A behavior. Conversely, learning orientation and Type A behavior should be negatively related.

\section{METHOD}

\begin{abstract}
Subjects
One hundred eighty-three Belmont University students were surveyed. The subjects were selected from various courses of study, in both upperand lower-level courses. Courses typically having large enrollments (e.g. more than 30 students) were identified, and permission for data collection was obtained from instructors. Of those who reported gender, 61 were men and 107 were women. The mean age was 23 years, and the range was 18-51. Of those who reported classification, $14 \%$ were freshmen, $31 \%$ sophomores, $31 \%$ juniors, and $24 \%$ seniors. The courseload status indicated that $89 \%$ of the subjects were full-time students
\end{abstract} and $11 \%$ were part-time students.

\section{Materials}

The LOGO II (Eison, 1981), a 32-item Likert-type scale, was used to measure grade orientation and learning orientation. Total mean scores of grade orientation ranged from 47.31 to 52.73 (Eison \& Pollio, 1989). Total mean scores of learning orientation range from 41.76 to 47.08 (Eison \& Pollio, 1989).

The Modified Jenkins Activity Survey (JAS; Jenkins, Zyanski, \& Rosenman, 1971), a 21-item multiple-choice questionnaire, was used to measure Type A/B behavior. Scores of 0-7 are associated with Type B behavior, and scores of 9 and higher are associated with Type $A$ behavior. A score of 8 has been established as the normative mean (McGregor, Eveleigh, Syler, \& Davis, 1991).

Academic dishonesty was measured by a 7-item questionnaire (Davis, Simon, Handler, \& Miller, 1992). This questionnaire requested information about frequency of cheating in high school (Question 1), fre- 
quency of cheating in college (Question 2), fear of being caught cheating (Question 3), improvement of scores via cheating (Question 4), the influence of strict penalties (Question 5), effective penalties (Question 6), and reasons for cheating (Question 7).

\section{Procedure}

The subjects were given an informed-consent form, a demographic sheet, and a self-administered booklet composed of the three questionnaires. All questionnaires were completed in the classroom during the regularly scheduled class time. To ensure anonymity, the informedconsent forms were completed and returned prior to completion of the demographic sheet and the questionnaire booklet.

The sequence of presenting LOGO II and JAS was counterbalanced to preclude order effects. Because it was potentially the most threatening instrument, the academic-dishonesty survey always appeared as the final instrument in the questionnaire booklet. The counterbalanced versions of the questionnaires were arranged alternately, prior to distribution in the classroom. Each subject was given a written debriefing when the questionnaires were completed. The debriefing statement explained the nature of each questionnaire and the hypotheses of the study.

\section{RESULTS}

Correlations among the Type A, LOGO II, and frequency-of-cheating scores were calculated. Negative relations existed between academic dishonesty and Type A behavior $[r(182)=-.166, p<.025]$, between grade orientation and Type A behavior $[r(182)=-.205, p<$ $.005]$, and between academic dishonesty and learning orientation $[r(182)=-.167, p<.025]$. Positive relations existed between learning orientation and Type $\mathrm{A}$ behavior $[r(182)=.402, p<.001]$ and between academic dishonesty and grade orientation $[r(182)=.199, p<$ .005 ]. Of the 183 subjects, $16 \%$ reported that they had cheated on a test in college and $84 \%$ reported that they had not cheated while in college.

\section{DISCUSSION}

The overall reported rate of cheating in the present study was $16 \%$. This rate is in accord with the results of the Davis, Grover, Becker, and McGregor (1992) study, which found that the lowest rate of reported cheating $(9 \%)$ occurred in a small, private, liberal arts college. In agreement with their data, our percentage is substantially below the $40 \%-60 \%$ range reported for larger institutions.

Initially, we reasoned that the relations among Type A behavior, grade orientation, and academic dishonesty would be positive. However, the present results indicated that Type A behavior, learning orientation, and lower rates of academic dishonesty were positively related. Conversely, it was found that Type B behavior, grade orientation, and higher rates of academic dishonesty were positively related.

The positive association between Type A behavior and learning orientation is the converse of our original prediction; it was anticipated that the competitive component of the Type A behavior pattern would be associated with competition for high grades. The present results suggest that the competitive characteristic of the Type A individual may be manifested as an intrinsic motivation for learning, rather than as an extrinsic motivation for grades. This finding agrees with prior research linking learning orientation and intrinsic motivation (Milton, Pollio, \& Eison, 1986). The positive relation between grade orientation and higher rates of academic dishonesty agrees with our original hypothesis. This association may be due to the importance that grade-oriented students place on grades, thus increasing the likelihood of cheating.

Finally, the present results highlight the need for research on academicdishonesty policies within institutions of higher learning. This need was echoed by Weaver, Davis, Look, Buzzanga, and Neal (1991). These investigators proposed that a model academic-dishonesty policy should include the following themes: academic integrity, responsibility, dishonest acts, honor code, procedures for handling cheating, punishment, and appeal. The difference between the cheating behavior of learningoriented and grade-oriented students that is revealed by the present study suggests that different types of sanctions may be necessary for these two groups of students.

\section{REFERENCES}

Davis, S. F., Grover, C. A., Becker, A. H., \& McGregor, L. N. (1992). Academic dishonesty: Prevalence, determinants, techniques, and punishments. Teaching of Psychology, 19, 16-20.

Davis, S. F., Simon, L., Handler, C., \& Miller, K. (1992, August). Academic dishonesty: One-time offenders or habitual criminals? Paper presented at the annual meeting of the American Psychological Association, Washington, D.C.

DraKe, C. A. (1941). Why students cheat. Journal of Higher Education, 12, 418-420.

EIson, J., (1981). A new instrument for assessing students' orientations towards grades and learning. Psychological Reports, 48, 919-924.

EIsON, J., \& Pollio, H. (1989). LOGO II: Bibliographic and statistical update. Cape Girardeau: Southeast Missouri State University, Center for Teaching and Learning.

Friedman, M., \& Rosenman, R. H. (1977). The key cause: Type A behavior pattern. In A. Monat \& R. H. Lazrus (Eds.), Stress and coping (pp. 203-212). New York: Columbia University Press.

Hetherington, E. M., \& Feldman, S. E. (1964). College cheating as a function of subject and situational variables. Journal of Educational Psychology, 55, 212-218.

Jenkins, C. D., Zyanski, S. J., \& Rosenman, R. J. (1971). Progress toward validation of a computer-scored test for the Type A coronaryprone behavior pattern. Psychosomatic Medicine, 133, 193-202.

Keller, M. (1976, August). Academic dishonesty at Miami. In Student life research (pp. 1-16). Oxford, Ohio: Miami University.

McGregor, L., Eveleigh, M., Syler, J. C., \& Davis, S. F. (1991). Self-perception of personality characteristics and the Type A behavior pattern. Bulletin of the Psychonomic Society, 29, 320-322.

Milton, O., Pollio, H., \& Eison, J. (1986). Making sense of college grades. San Francisco: Jossey-Bass.

Singhal, A. C. (1982). Factors involved in students' dishonesty. Psychological Reports, 51, 775-780.

Weaver, K. A., Davis, S. F., Look, C., Buzzanga, V. L., \& NeAL, L. (1991). Examining academic dishonesty policies. College Student Journal, 25, 302-305.

(Manuscript received September 12, 1992.) 